Departments of Urology (Prof. S. SATo) and of Anatomy (Prof. T. Fujita), Niigata University School of Medicine, Niigata, Japan

\title{
Occurrence and Structure of Intercellular Bridges between the Human Spermatogonia
}

\author{
Yasuo Togawa
}

\author{
Received July 15, 1971
}

\begin{abstract}
Summary. The intercellular bridges between the spermatogonia in adult man were observed by electron microscopy with the following results.

The bridges were usually barrel-shaped with a slight convexity at the middle $(1.0-1.5 \mu$ both in diameter and length). A layer of an electron dense material (40-50 m $\mu$ thick) occurred directly beneath the plasma membrane of the bridges. Besides various cytoplasmic organelles, microtubules were frequently found in the bridges.

The bridges were demonstrated between type $A$ as well as type $B$ spermatogonia. It was proposed that the synchronizing differentiation, by means of the intercellular bridges, of the germ cells starts from the division of "dark type $A$ " spermatogonia into "pale type A" spermatogonia (designation by CLeRnonT), and that thereby it is possible to yield groups of, at the most, thirty-two interconnected spermatids. The concept of $F_{A \text { WCETT }}$ (1961) that the intercellular bridge first occurs between primary spermatocytes as result of the last spermatogonial division and that the groups of eight interconnected spermatids are subsequently formed was criticized.
\end{abstract}

The intercellular bridges as a normal occurrence in spermatogenesis were first demonstrated with the electron microscope by BuRGos and FAWCETT (1955) in the spermatids of adult cats. On the basis of subsequent observations (FAwCETT and ITO, 1958; Fawcett, Ito and Slautterback, 1959), Fawcett (1961) suggested that in the last spermatogonial division, the cytoplasmic communication between the primary spermatocytes remained as a result of incomplete cytokinesis after resorption of the spindle remnant, giving rise to four interconnected secondary spermatocytes, and consequently to eight spermatids connected by intercellular bridges (Fig. 13B). As the cytoplasm of the bridges included cell organelles identical with those in the interconnected cells, FAwCETT (1961) further speculated that the organelles could pass through the bridges from cell to cell and that the bridges were responsible for maintaining the synchronized differentiation of the germ cells. This hypothesis of FAWCETT subsequently was supported by many investigators.

Some authors, meanwhile, postulated that intercellular bridges of corresponding nature might play a role in synchronization in oogenesis in the ovaries of some mammals (ZAmboni and Gondos, 1968; Gondos and Zamboni, 1969; Ruby, Dyer and Skalko, 1969). The bridges between the developing oocytes were postulated to serve as a channel for the transfer of nutrients from "nurse cells" to the oocyte (RUBY, Dyer and Skalko, 1969; Ruby et al., 1970). On the other hand, degeneration of the germ cells in oogenesis and in spermatogenesis was postulated to be synchronized by the existence of the bridges by some authors (BuRGos and FAWCETT, 1955; ZAMBONI and Gondos, 1968; Gondos and Zamboni, 1969; Gondos and Zemjanis, 1970).

Recently, NiCANDER (1967) and NiCANDER and PlöEN (1969) reported the occurrence 
of the bridges between type B spermatogonia in the rabbit. The bridges were further described in the spermatogonia of monkeys by Gondos and ZEMJANIs (1970) and in human spermatogonia by VILAR, Paulsen and Moore (1970). However, there have been no reports on the occurrence of a bridge between type A spermatogonia in mammalian testis.

In the present electron microscope study, the author recognized the bridges not only between type B spermatogonia, but also between type A spermatogonia in the adult human testis. The present report attempts first to define the fine structure of the bridges in the spermatogonia, and second to provide further insight into the possible large number of spermatids interconnected and synchronized by the bridges.

\section{Materials and Methods}

Materials were obtained from five adult patients diagnosed as having intrascrotal disorders by testicular biopsy under local or spinal anesthesia. The specimens were fixed in $2.5 \%$ glutaraldehyde buffered with $0.1 \mathrm{M}$ phosphate at $\mathrm{pH} 7.4$ for $2 \mathrm{hrs}$, followed by post-fixation in $1 \%$ osmium tetroxide for $1-2 \mathrm{hrs}$. The specimes were dehydrated with a series of ascending concentrations of ethanol and embedded in Epon 812 (LuFT, 1961). Thin sections for electron microscopy were made with glass knives on a Porter-Blum MT-I microtome, doubly stained with uranyl acetate and lead hydroxide (MILlONIG, 1961) and were examined with a Hitachi HS-7s electron microscope.

Specimens showing normal histological features of the germinal epithelium were selected as the material for this study. For this purpose thick sections $(1-2 \mu)$ of the Epon embedded tissues were stained with $0.5 \%$ toluidine blue to be examined under the light microscope.

\section{Observations}

The spermatogonia appear as oval and flat-shaped cells and are attached to or located near the basement membrane of the seminiferous epithelium. Two types of human spermatogonia are distinguished according to the criteria of nuclear fine structure proposed by TRES and SolARI (1968). Type B spermatogonia are characterized by an oval nucleus showing heterogeneous chromatin, whose flakes are dispersed in the nucleus. The nucleolus which is rarely seen is usually not attached to the nuclear membrane (Fig. 1). On the other hand, the nucleus of type A spermatogonia is slightly flat and appears much more homogeneous than that of the type $B$ cells. The nucleus of the type A spermatogonia has frequently one or more nucleoli associated with the nuclear membrane (Fig. 2) and a clear space without sharp boundary measuring $1-4 \mu$ in diameter (Fig. 3). The nuclei including this clear space tend generally to have a more irregular flat shape and darker chromatin than otherwise (Fig. 4). As the cytoplasm of the type A spermatogonia is similar to that of the type $B$ cells, it is difficult to distinguish between both types of cells by the cytoplasmic structure. In the type A spermatogonia, however, two or more mitochondria tend to be aggregated together with an electron dense intermitochondrial material (Fig. 2).

Between the type A spermatogonia (the cells having nucleoli associated with the nuclear membrane and/or showing a clear space in the nucleus) and between the 
type B spermatogonia, a cytoplasmic bridge showing a characteristic fine structure (vide infra) is frequently found (Fig. 1-3, 5, 6). As both spermatogonia connected by the bridge are always similar in their nuclear and cytoplasmic features, they often

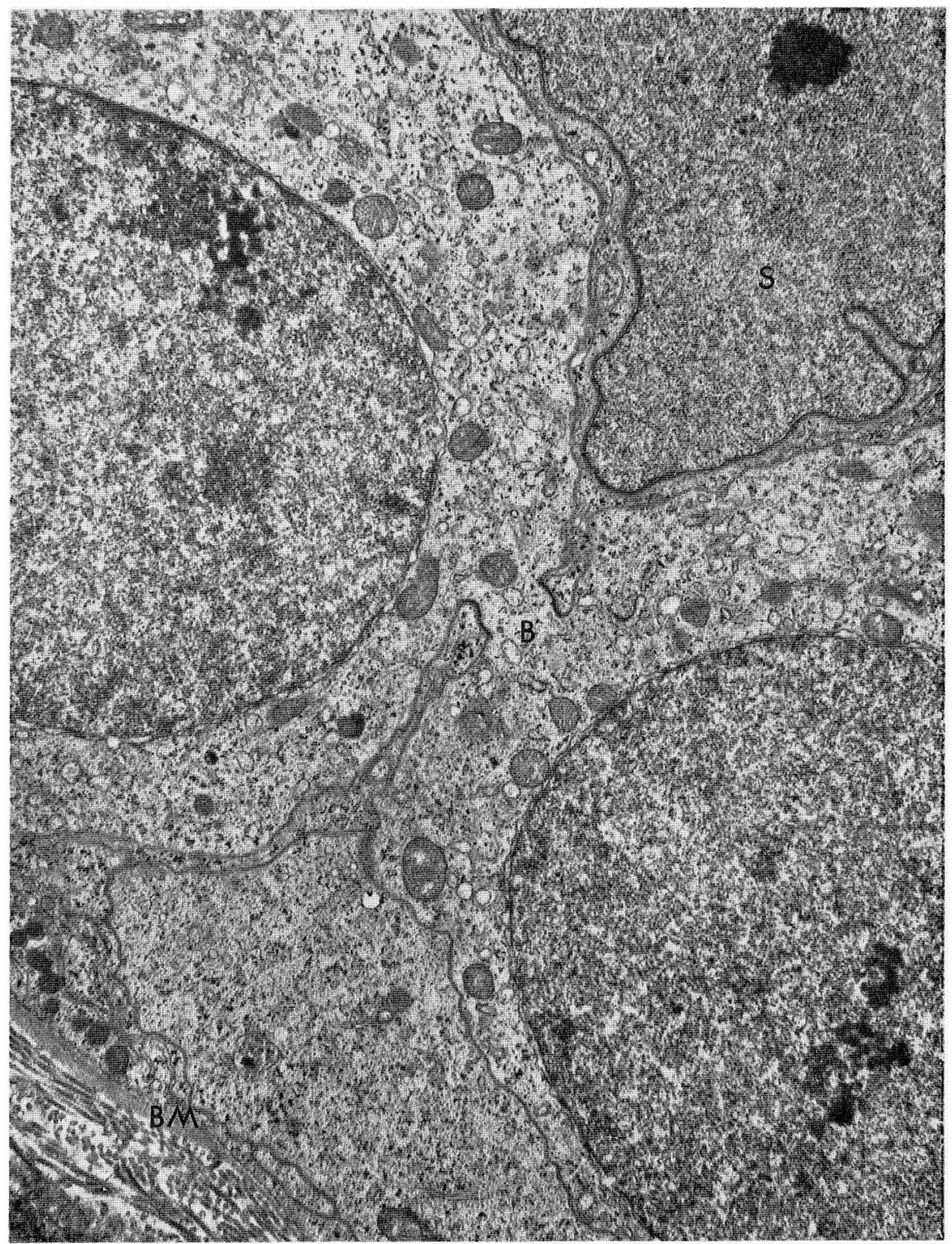

Fig. 1. Two type B spermatogonia are connected by a bridge $(B)$, which is surrounded laterally by the slender processes of Sertoli cells $(S)$. The nuclei of these cells show heterogeneous chromatin forming numerous flakes. $B M$ basement membrane. $\times 5,500$ 


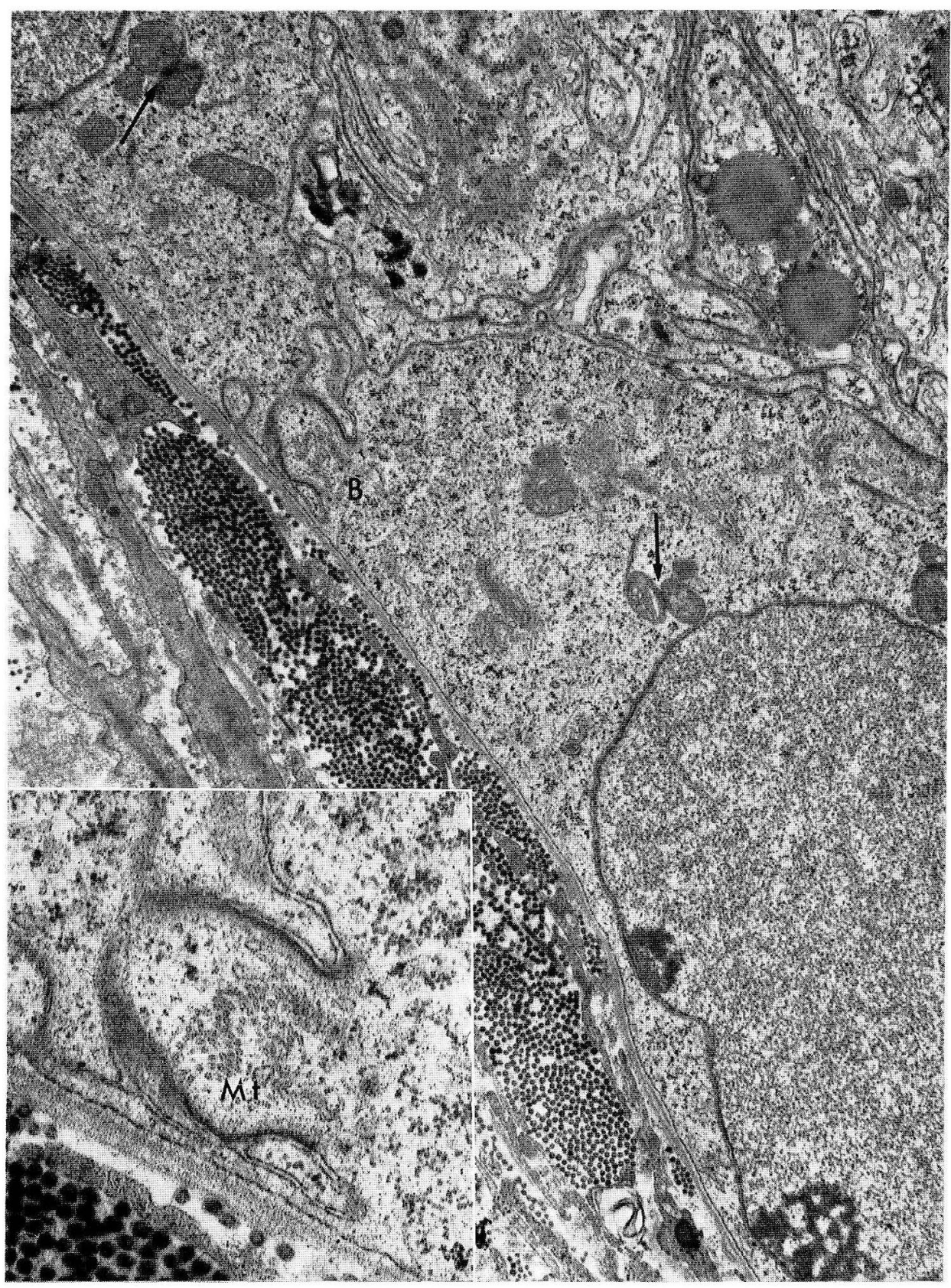

Fig. 2. Two connected type A spermatogonia are attached to the basement membrane. The nucleus of these cells is much more homogeneous than the nuclei in Figure 1 and has two nucleoli associated with the nuclear membrane. The mitochondria appear to be aggregated with intermitochondrial material (arrows). $\times 6,500$. Insert. The same bridge $(B)$ at higher magnification. Note many microtubules $(M t)$ in the bridge. $\times 19,500$ 
exhibit a "mirror-image" appearance in an appropriate section including both cells and the bridge inbetween (ZAmboni and Gondos, 1968; Gondos and Zemjanis, 1970).

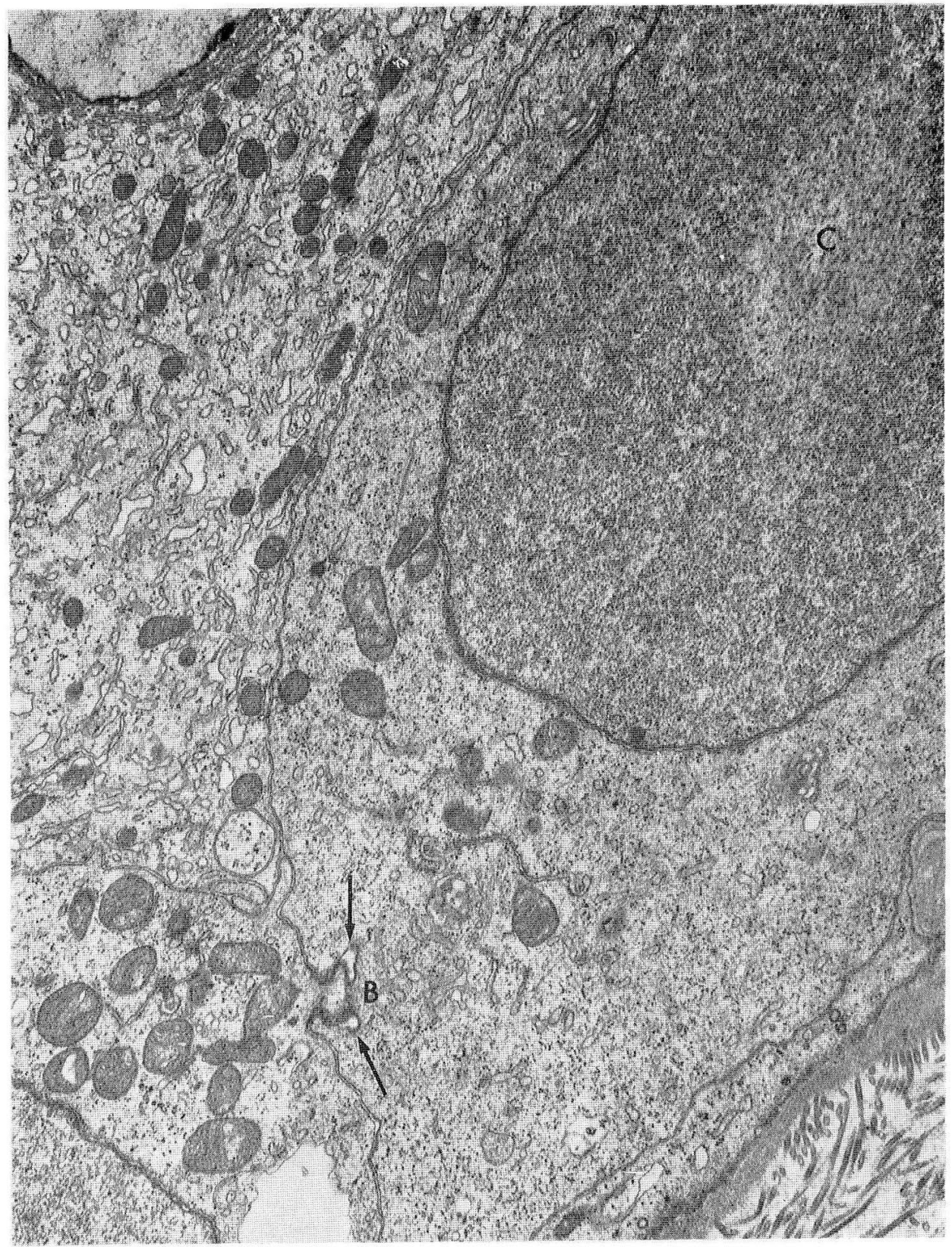

Fig. 3. One type A spermatogonium with a nucleus containing homogeneous chromatin and a clear space $(C)$ is connected with another cell. Notc the reflection of the plasma membrane of the right cell to sides of the bridge $(B)$. Here small dilated spaces (arrows) are formed. $\times 7,000$ 
It is, therefore, thought that the connected cells are always at an identical stage of differentiation (Fig. 1, 4).

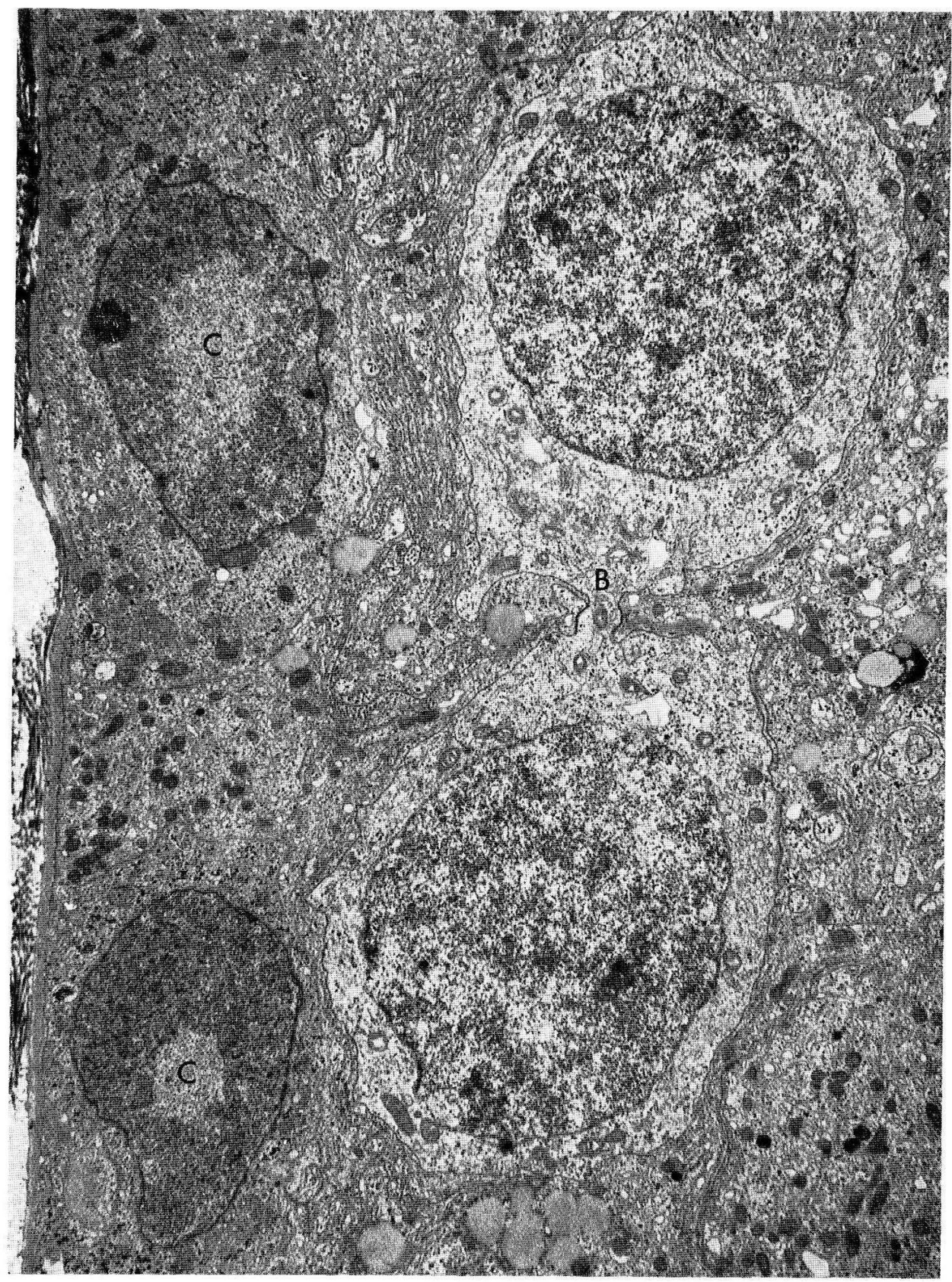

Fig. 4. Two primary spermatocytes of similar morphological features are connected by a bridge $(B)$. Two type A spermatogonia with a clear space $(C)$ are attached to the basement membrane. $\times 3,700$ 
The bridges are generally round or oval in cross sections (1.0-1.5 $\mu$ in diameter) (Fig. 7) and appear slightly convex at the central portion in longitudinal sections (1.0-1.5 $\mu$ in length) (Fig. 6, 8). The three-dimensional form of the bridge is thus considered to be barrel-like (RuBy, Dyer and Skalko, 1969).

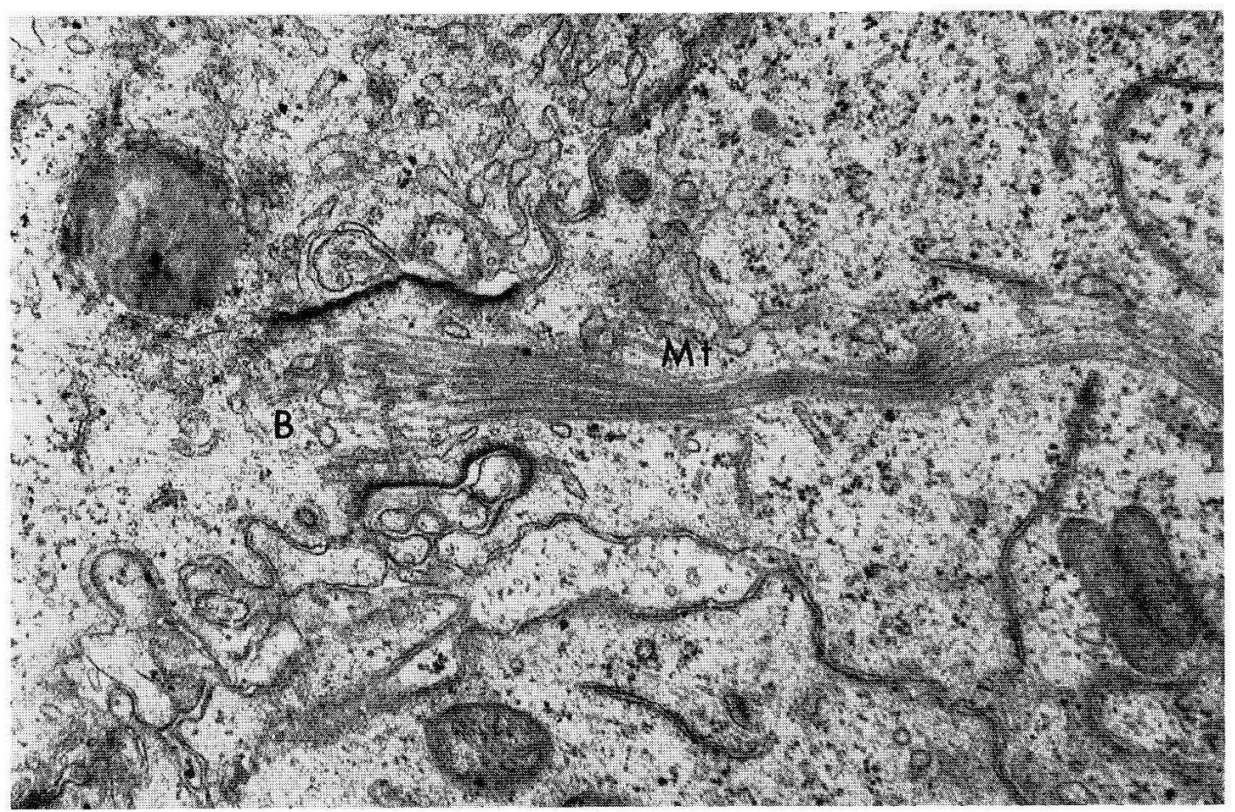

Fig. 5. A bridge $(B)$ between spermatogonia. Note a bundle of long microtubules $(M t)$ extending from the bridge into the cell. $\times 11,000$

The bridges are bounded laterally by a membrane which is continuous to the plasma membrane of the conjoined cells. A layer of an electron dense material, measuring $40-50 \mathrm{~m} \mu$ in thickness, lies immediately beneath the plasma membrane of the bridges (Fig. 6-8). In general this material covers just the full length of the bridges but rarely extends beneath the plasma membrane of the conjoined cells. The presence of these dense borders facilitated the identification of the bridges under the eleclron microscope.

Many cytoplasmic organelles occur within the bridges including mitochondria, free ribosomes, cisterns of smooth and rough endoplasmic reticula, the Golgi complex and some vesicles (Fig. 6-9). Microtubules are also frequently seen in the bridges, running more or less parallel to the long axis of the bridge and extending deeply into the conjoined cells (Fig. 2, 6, 7). In some bridges they form a conspicuous bundle (Fig. 5,10 ), but they never completely fill the bridge as the spindle remnant in mitosis does. Neither can be seen the dense middle disc which characterizes the spindle remnant. Some of the microtubules possess a dense core in cross sections (Fig. 7).

The bridges are irregularly surrounded by the processes of either Sertoli cells or germ cells, or of both cells, leaving a space of approximately $20-30 \mathrm{~m} \mu$. This relation was found in both cross (Fig. 7) and longitudinal sections (Fig. 1, 2, 4, 6, 8) of the bridges. When the plasma membrane of the connected cells bends in the opposite 
direction to cover the bridge, a small intercellular dilated space is formed at the base of the bridges (Fig. 3).

When two interconnected cells are in positions separated from each other, one of these cells possesses a slender cytoplasmic process continuing to the bridge. In this case the bridge itself is also narrower than otherwise and its dense borders are not convex but straight or concave (Fig. 10).

Two spermatogonia connected by a bridge were frequently encountered in the present study, but the author could not find three or more cells interconnected simultaneously.

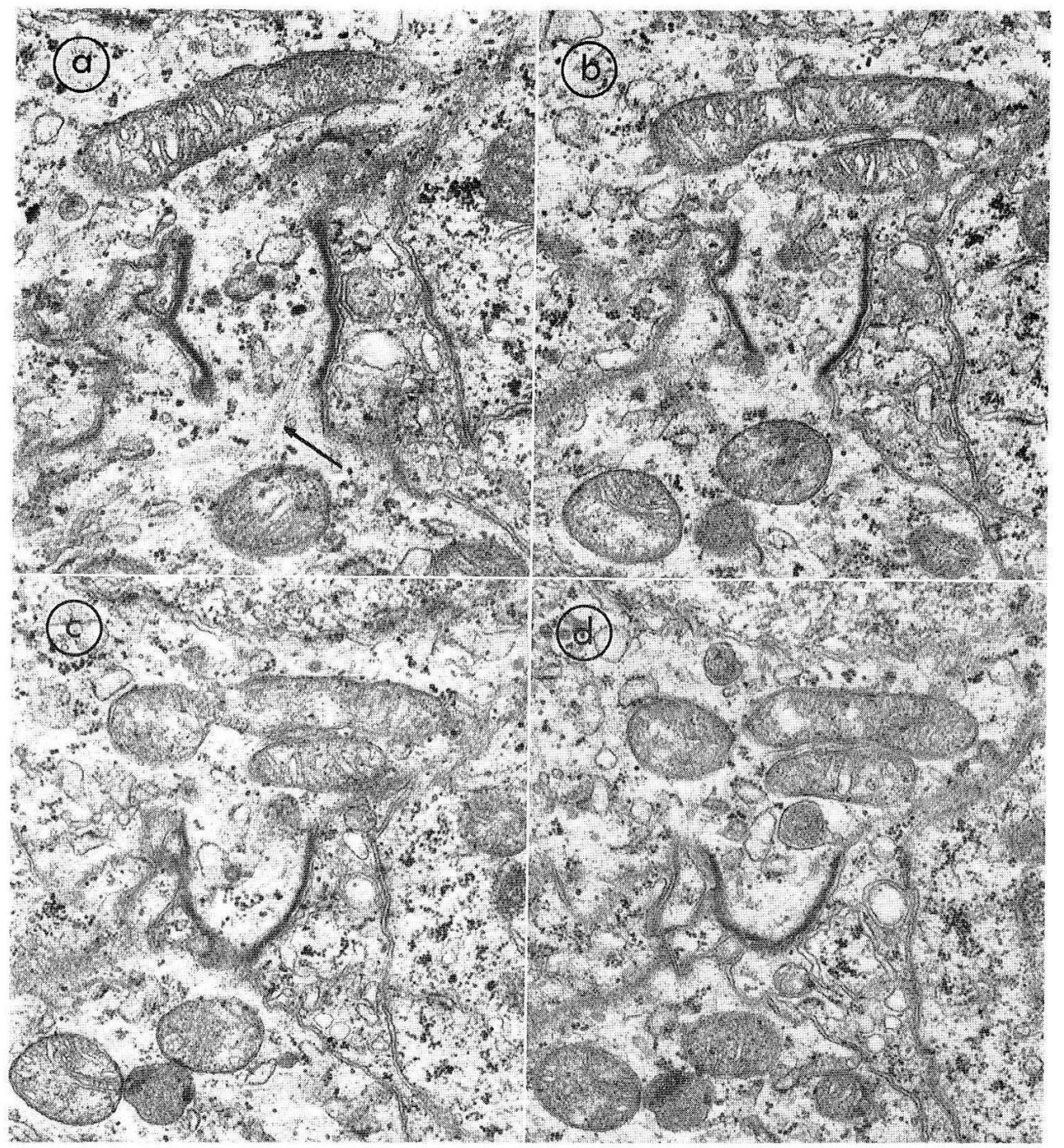

Fig. 6. A serial section of a bridge between type B spermatogonia. In a section through the center: of the bridge (a), its barrel shape is clearly seen. In other sections (b, c), the shape of the bridge appears more or less irregular. In the last section (d) the bridge is hardly recognized as such. Note a few microtubules (arrow). $\quad \times 13,500$ 


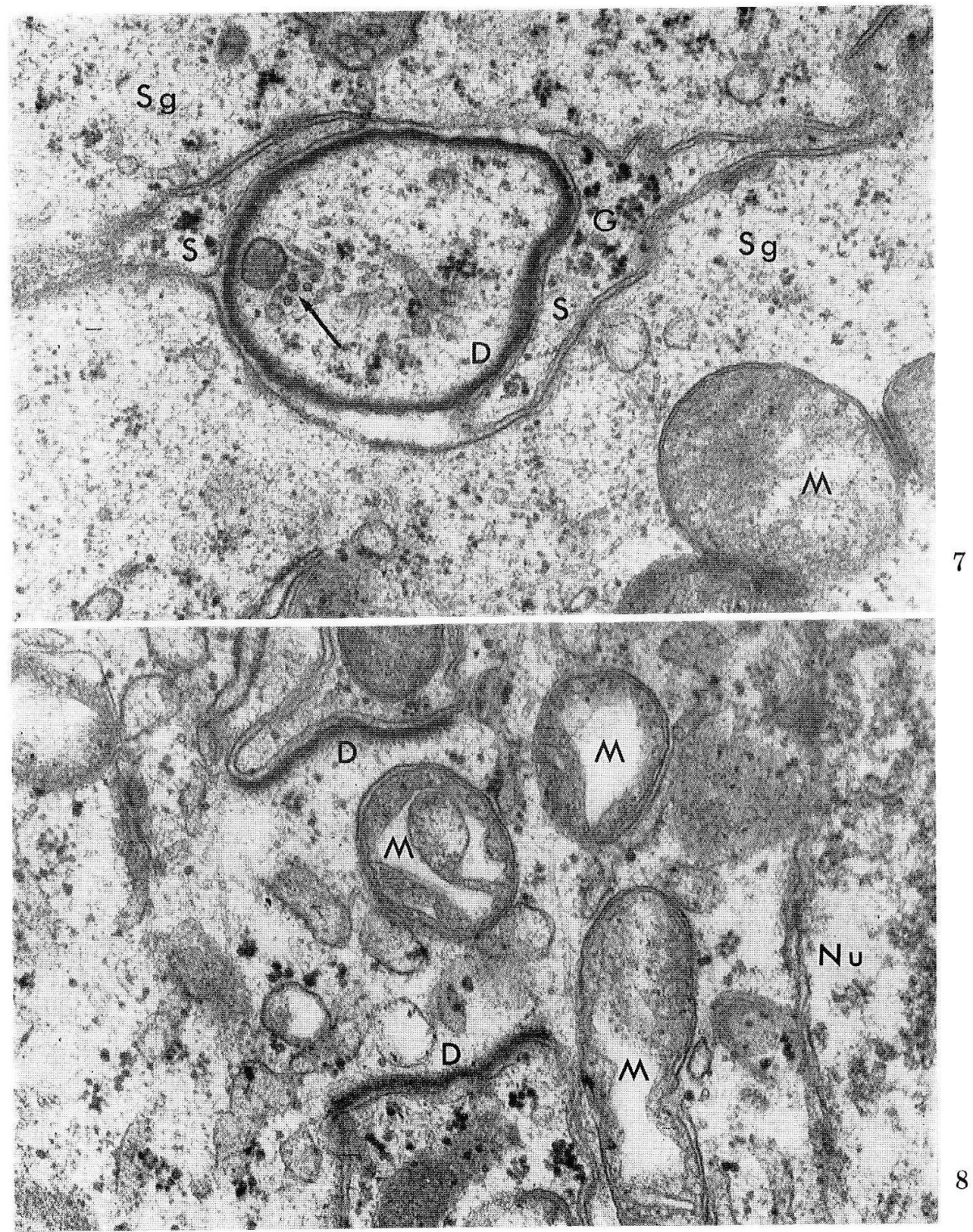

Fig. 7. A cross-sectioned bridge (probably between spermatogonia). A layer of dense material $(D)$ lies directly beneath the plasma membrane of the bridge, which is surrounded by the cytoplasmic profiles probably corresponding to spermatogonia $(S g)$ and Sertoli cells $(S)$. Note the cross-sectioned microtubules having a dense core (arrow). G glycogen particles, $M$ mitochondria. $\quad \times 28,000$

Fig. 8. A longitudinal section of a bridge between primary spermatocytes. The bridge is bounded laterally by a dense material $(D)$ covering the full length of the connection. Various cell organelles are seen in the bridge. $M$ mitochondria, $N u$ nucleus. $\times 28,000$ 
Various types of bridges observed in the present study are illustrated in Figture 11.

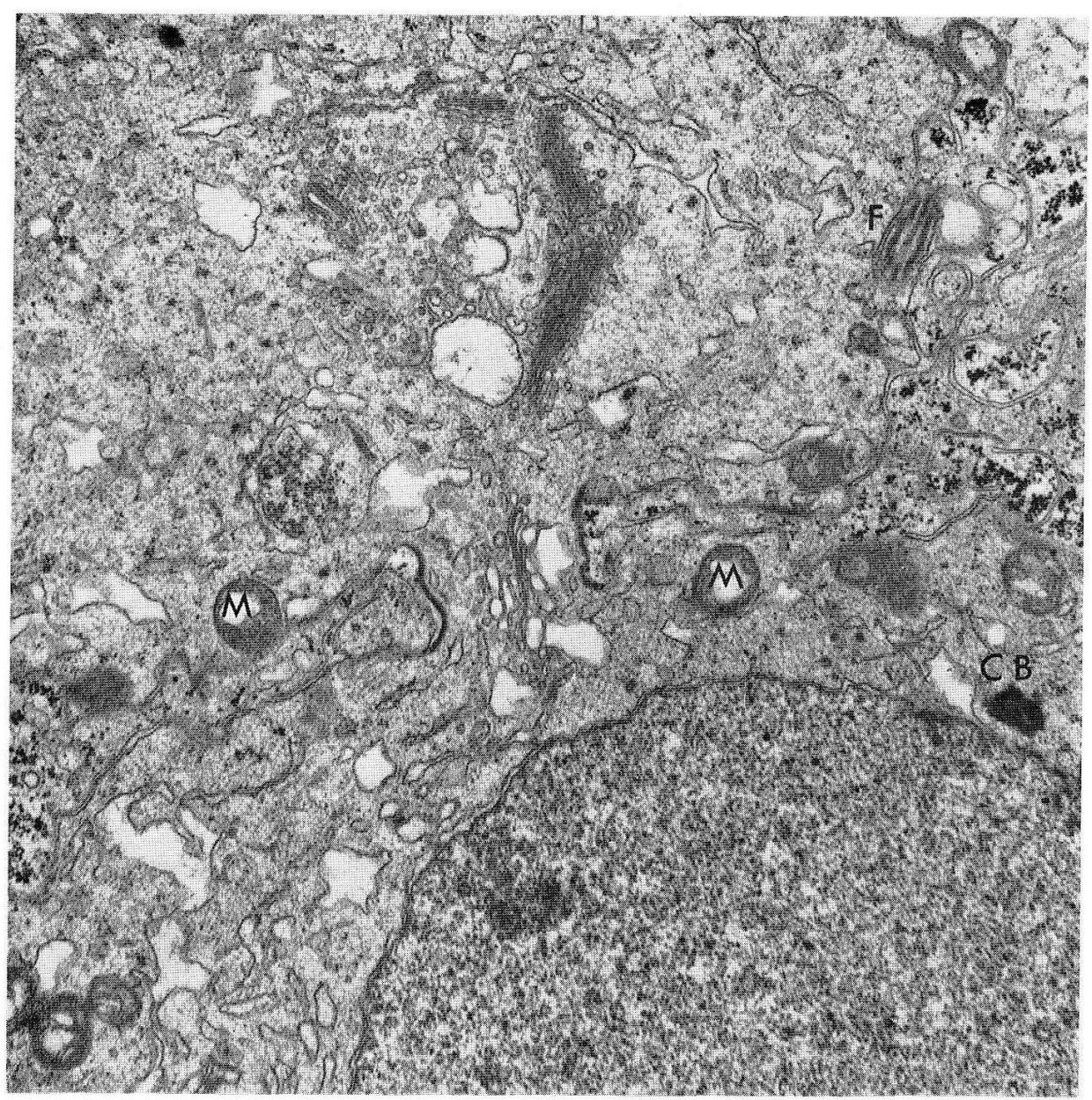

Fig 9. A bridge $(B)$ between immatured spermatids. Note the conspicuous Golgi complex in the bridge. $C B$ chromatoid body, $F$ flagellum, $M$ mitochondria. $\quad \times 9,600$

\section{Discussion}

In somatic division the spindle bridge is transiently formed when the cleavage furrow is temporarily arrested by the spindle remnant. The spindle remnant is soon resorbed and the cell is completely divided giving rise to two daughter cells. In germ cell division the cleavage of the cell is arrested as in somatic division, but the intercellular bridge thus formed is characterized in this case by its persistence throughout generations of the daughter cells.

The intercellular bridge in germ cells is further characterized by the occurrence of an electron dense material beneath the plasma membrane. This structure was first 
described by Burgos and F $\Lambda$ WCETT (1955) as a "dark ring" in cat spermatids. A few years later, Mercer and WolPERT (1958) described a similar structure in sea urchin eggs as a morphological equivalent of the "contractile ring" hypothetically proposed by Marsland and Landau (1954). Fawcett, Ito and Slautterback (1959) and FAWCETT (1961) stated that the dense material might simply reinforce and stiffen the bridges. Gardner and Holyoke (1964), on the other hand, interpreted this material as a condensation of RNA on the basis of its affinity to uranyl stains for nucleic acids.

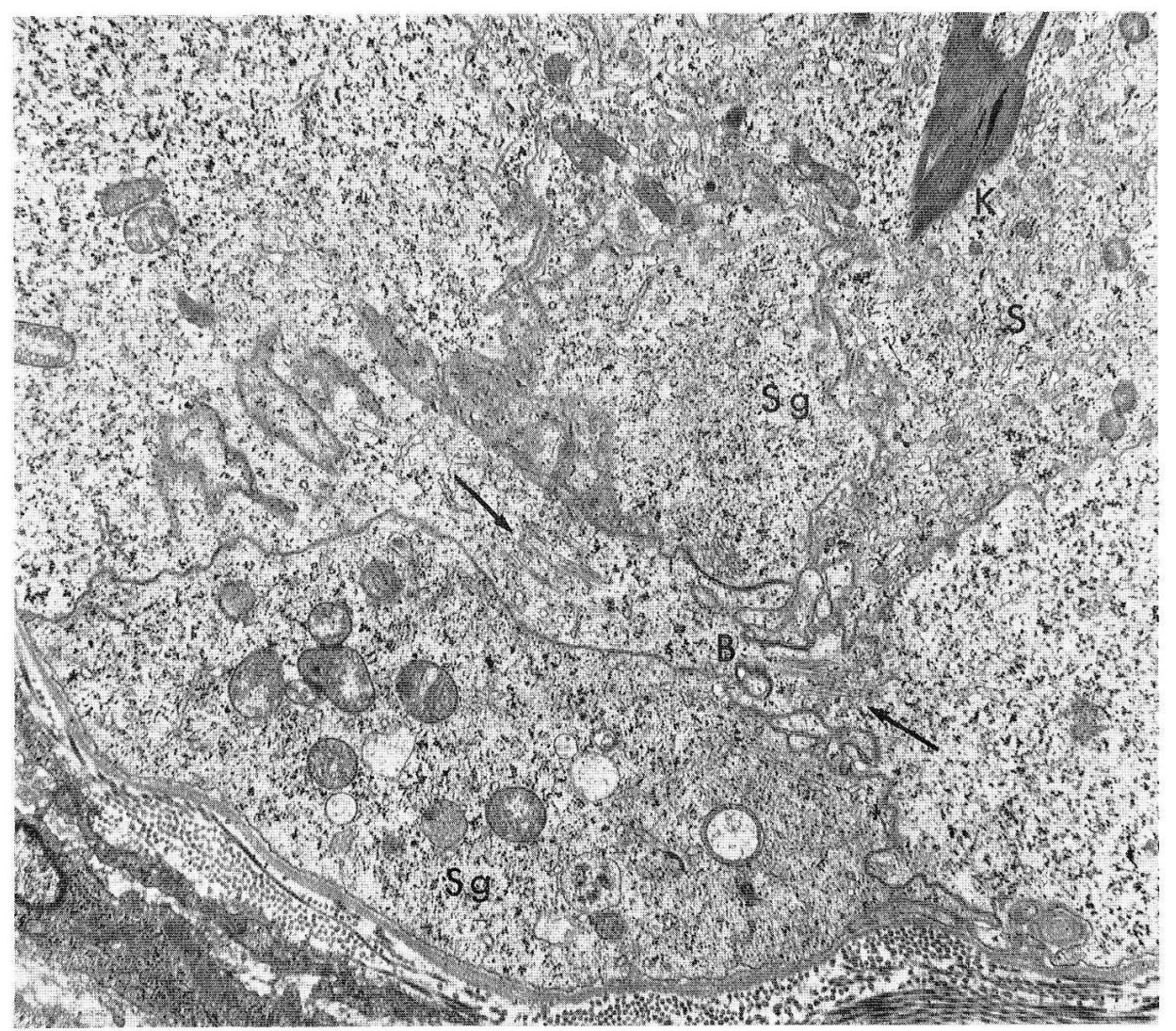

Fig. 10. A bridge $(B)$ showing slightly concave borders is continuous to a slender cytoplasmic process of the left spermatogonium. Note a bundle of microtubules (arrows). $K$ Charcot-Böttcher's crystalloid, S Sertoli cell, Sg spermatogonium. $\quad \times 4,200$

Recently, Koch and KIng (1969) and KING and AkaI (1971) found a dark rim of the ring canal (intercellular bridge) in the female germ cells of Drosophila melanogaster and in the male germ cells of Bombyx mori, respectively. These authors are again of the opinion that the dense rim derives from the contractile ring and represents a metabolically active organelle. Though further studies, especially histochemical examinations, are needed to elucidate this problem, the author is inclined to Fawcett's hypothesis of supporting structure.

It remains to be clarified whether the dense matcrial around the intercellular 
bridge might also occur in somatic division. As far as the author knows, only one report describing that the contractile ring occurred in HeLa cell division (ScHROEDER, $1970)$ is available in this connection.

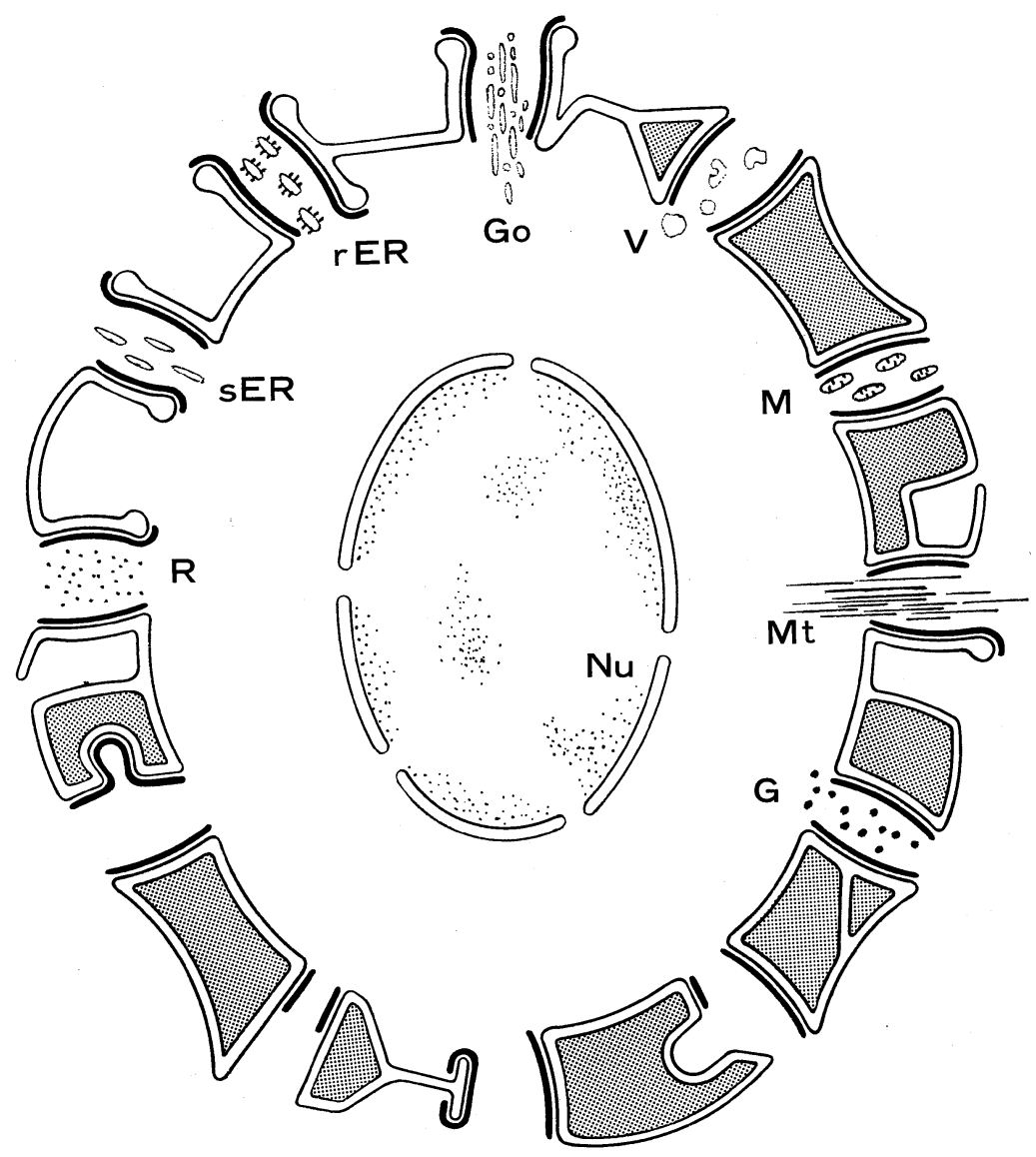

Fig. 11. A drawing illustrating the various possibilities of the structure and surrounding elements of the intercellular bridges of germ cells which have been observed in their longitudinal sections in this study. The white spaces indicate the cytoplasm of germ cells while the grey parts, the cytoplasm of Sertoli cells $(S)$. $G$ glycogen particles, $G o$ Golgi complex, $M$ mitochondria, $M t$ microtubules, $N u$ nucleus, $R$ ribosomes, $r E R$ rough endoplasmic reticulum, $s E R$ smooth endoplasmic reticulum, $V$ vesicles.

Microtubules have been found in a variety of cells including the spermatogonia (NAGANo, 1967; VILAR, PAUlsen and Moore, 1970) and are usually interpreted as cytoskeletal elements (FAWCETT, 1966). It is characteristic in this study that microtubules were frequently recognized in the bridges. SLAUTTERBACK (1963) found microtubules in the intercellular bridges in the interstitial cells of the Hydra and interpreted them as remnants of the mitotic spindle. On the other hand, the existence of microtubules in the bridges between mammalian germ cells has never been recognized in previous 
reports. In the present study the microtubules in the bridge do not exhibit the "dense disc" or "mit-body" which characterizes the spindle remnant in somatic division (Buck and Tisdale, 1962; Allenspach and Roth, 1967; King and Akai, 1971). Furthermore, the present study revealed a dense core in the cross sections of the microtubules which is lacking in spindle fiber remnants. The author, therefore, presumes that the microtubules in the present study differ from the spindle remnant.

As stated above, intercellular bridges have been reported to occur between type B spermatogonia in the rabbit by Nicander (1967) and by NiCANDER and PlöEN (1969). Gondos and ZEMJANis (1970) demonstrated the bridges between spermatogonia of the monkey, but the cell types were not indicated. Vilar, Paulsen and Moore (1970) classified human spermatogonia into two types, i.e., flat and round spermatogonia, and stated that the bridges were seen between round type spermatogonia.

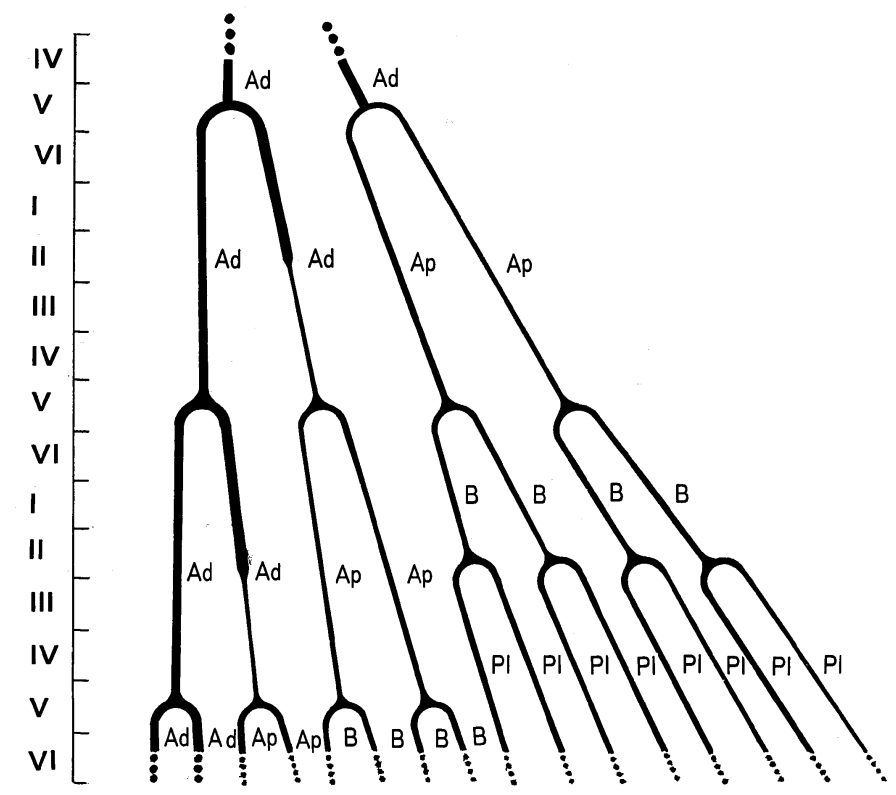

Fig. 12. Diagram showing the view of Clermont on the differentiation of human germ cells. Courtesy of Dr. Clermont, redrawn from the Amer. J. Anat. 118: 509-524 (1966a).

According to the nuclear morphology by CLERMONT (1963) using the light micro scope, human spermatogonia are classified into three types of different developmental stages, i.e., into dark type A (Ad), pale type A (Ap) and type B spermatogonia (B). He found that the cell ratio $\mathrm{Ad}: \mathrm{Ap}: \mathrm{B}: \mathrm{Pl}$ (preleptotene primary spermatocyte) was $1: 1: 2: 4$ in the human seminiferous tubules. He further showed that the dark and pale type A spermatogonia were generally arranged in homogeneous groups within which the cells of identical types occurred in pairs. On the basis of these finidngs, CleRmont (1966a, b) presumed that one dark type A spermatogonium divides, by an equivalent mitosis, to yield a pair of dark type A spermatogonia, one of which repeats the same divisions but the other produces a pair of more differentiated pale type A spermatogonia; the latter in turn would yield four type B 


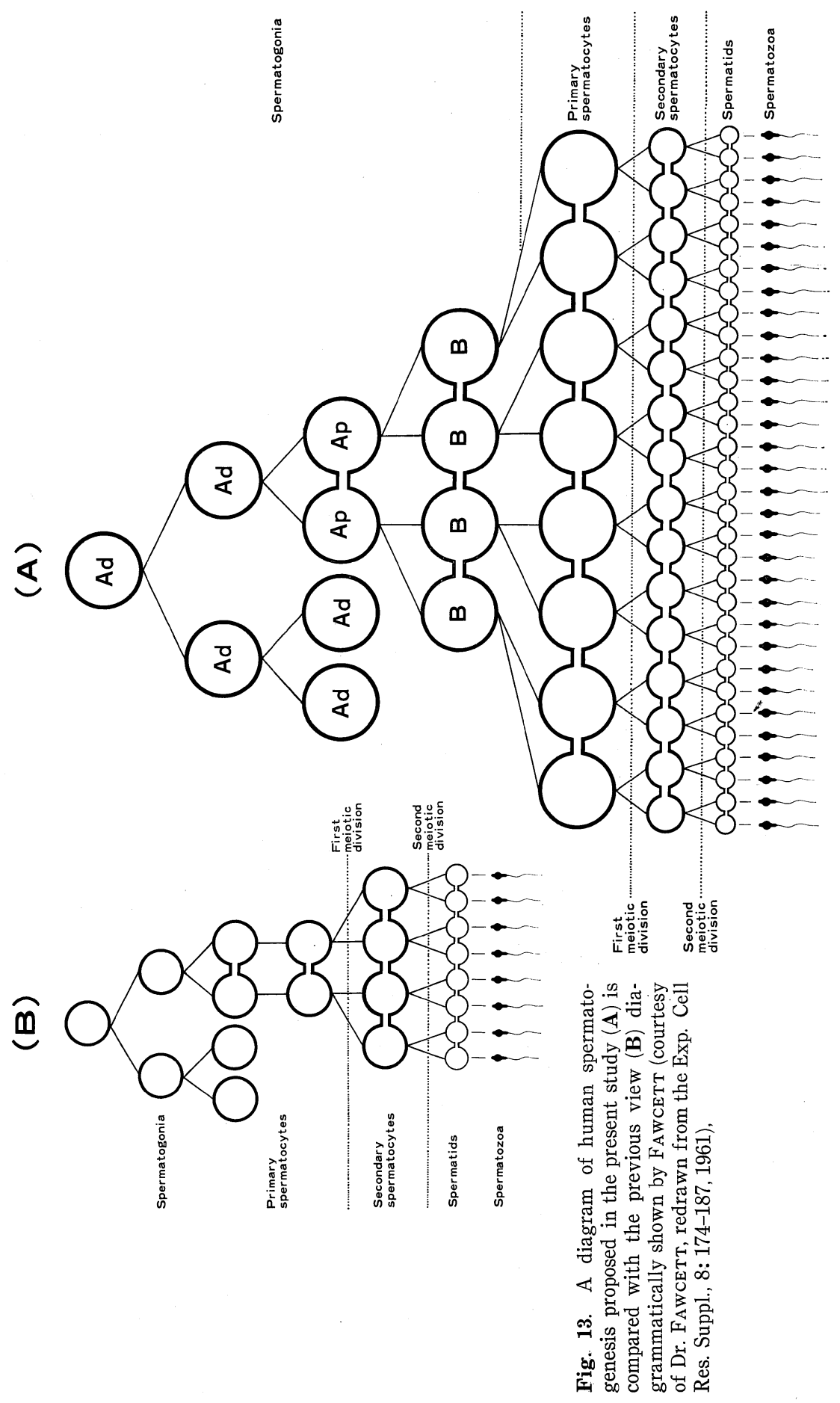


spermatogonia which would give rise to a cell group consisting of eight primary spermatocytes (Fig. 12).

The present electron microscope finding on the occurrence of the bridges between the human type A spermatogonia indicates that the bridges must exist between the dark type A and/or between the pale type A spermatogonia. Although TREs and SolARI (1968) suggested in their electron microscope study of the human testis the existence of "at least two subtypes of human type A spermatogonia," dual forms of cells which might correspond to the dark and pale subtypes of CLERMONT (1963) have not been identified at the ultrastructural level as yet.

It is generally accepted that differentiation of germ cells of identical types is synchronized, and the intercellular bridges connecting them are thought, as mentioned above, essential for this synchronization of the cells at least in mammalian spermatogenesis. The intercellular bridges, then, must theoretically occur between the germ cells of identical type. In the present study, in fact, the bridges were found only between the germ cells (including type A spermatogonia) in identical stages. According to the model of spermatogonial renewal suggested by CLERMONT (1966a, b), the earliest cell division which produces always identical cells is that of the dark type A producing the pale type A spermatogonia. Thus, if Clermont's hypothesis be true, the bridge is thought to be first formed in the division of the dark type A spermatogonia into a pair of pale type A spermatogonia, and to occur consequently in the germ cells of successive generations down to the spermatids. It is, therefore, possible that two conjoined type A spermatogonia, by subsequent formation of intercellular bridges, continue to be synchronized in differentiation, and finally theoretically produce thirty-two spermatids interconnected by thirty-one bridges (Fig. $13 \mathrm{~A}$ ). There seems to be no reason for Fawcett's hypothesis that the bridge first occurs between primary spermatocytes as a result of the last spermatogonial division, and that in spermatids the groups of eight cells interconnected by the bridges are formed (Fig. $13 \mathrm{~B}$ ).

NiCANDER (1967) observed two conjoined type B spermatogonia and three interconnected primary spermatocytes in the rabbit, and interpreted this finding as indicative of the possible production of up to sixteen interconnected spermatids. The observation of four spermatogonia interconnected by bridges in the monkey (GoNDOs and ZEMJANIS, 1970) indicates also that the bridges may exist between spermatogonia which are at least one generation less mature than the most matured spermatogonia.

On the other hand, it is well known that the differentiating germ cells are apt to degenerate at various stages in spermatogenesis. The population of the degenerating germ cells conspicuously varies among mammalian species and according to investigators (Roosen-Runge, 1955; OAkberg, 1956; Clermont, 1962; Swierstra and Foote, 1963; Clermont and Bustos-Obregon, 1968; Clermont, 1969). It has been recently reported by CleRMONT and Bustos-OBREGON (1968) that in the rat the number of primary spermatocytes produced was only $45 \%$ of the number that could theoretically be produced if all spermatogonia differentiated without degeneration. Although no quantitative data of this kind is available concerning human spermatogenesis, it must be noticed that the thirty-two human interconnected spermatids theoretically given in the present paper may, in reality, be much reduced by the occurrence of cell degeneration. 
Acknowledgements. The author wishes to thank Prof. T. Fujita and Prof. S. Sato for providing advice and criticism during the course of this work.

\title{
ヒトの精祖細胞間にみられた細胞間橋の出現と構造について
}

\author{
外川八洲雄
}

正常の精子発生のみられた成人の精巣を電子顕微鏡で観察した.

細胞間橋は直径 $1.0-1.5 \mu$ ，長さ $1.0-1.5 \mu$ で，中央部のやや膨隆した標状構造と考 えられ，厚さ $40-50 \mathrm{~m} \mu$ の 1 層の電子密度の高い物質が細胞膜直下を取り巻いていた. しばしば 微細小管が細胞間橋内に認められた。

この細胞間橋が B 型精祖細胞間ばかりでなく，A型精祖細胞間にも存在することが確 認された. このことから，細胞間橋による精細胞分化の同期化は，CLERMONT の呈示し た暗調 A 型精祖細胞の明調 A 型精祖細胞への分裂からはじまり，その結果として，細胞 間橋によって 最高 32 個の互に連結した精子細胞のグループを生ずる可能性があると推 察された.この見解は，細胞間橋は第一次精母細胞間から存在し，8個の精子細胞が連 結するという FAWCETT（1961）の仮説と異なる.

\section{References}

Allenspach, A. L. and L. E. Roth: Structural variations during mitosis in the Chick embryo. J. Cell Biol. 33: 179-196 (1967).

Buck, R. C. and J. M. Tisdale: The fine structure of the mid-body of the rat erythroblast. J. Cell Biol. 13: 109-115 (1962).

Burgos, M. H. and D. W. Fawcett: Studies of the fine structure of the mammalian testis. I. Differentiation of the spermatids in the cat (Felis domestica). J. biophys. biochem. Cytol. 1: 287300 .(1955).

Clermont, Y.: Quantitative analysis of spermatogenesis of the rat: a revised model for the renewal of spermatogonia. Amer. J. Anat. 111: 111-129 (1962).

: The cycle of the seminiferous epithelium in man. Amer. J.Anat. 112: 35-52 (1963).

: Renewal of spermatogonia in man. Amer. J. Anat. 118: 509-524 (1966a).

: Spermatogenesis in man: a study of the spermatogonial population. Fertil. Steril. 17: 705-721 (1966b).

-: Two classes of spermatogonial stem cells in the monkey (Cercopithecus aethiops). Amer. J. Anat. 126: 57-72 (1969).

Clermont, $\mathbf{Y}$. and E. Bustos-Obregon: Re-examination of spermatogonial renewal in the rat by means of seminiferous tubules mounted "in toto". Amer. J. Anat. 122: 237-248 (1968).

Fawcett, D. W.: Intercellular bridges. Exp. Cell Res. Suppl. 8: 174-187 (1961).

: An atlas of fine structure. The cell. Philadelphia and London, W. B. Saunders Co. 1966.

Fawcett, D. W. and S. Ito: Observations on the cytoplasmic membranes of testicular cells, examined by phase contrast and electron microscopy. J. biophys. biochem. Cytol. 4: 135-142 (1958).

Fawcett, D. W., S. Ito and D. Slautterback: The occurrence of intercellular bridges in groups of cells exhibiting synchronous differentiation. J. biophys. biochem. Cytol. 5: 453-460 (1959).

Gardner, P. J. and E. A. Holyoke: Fine structure of the seminiferous tubule of the Swiss mouse. I. The limiting membrane, Sertoli cell, spermatogonia, and spermatocytes. Anat. Rec. 150: 391-404 (1964). 
Gondos, B. and L. Zamboni: Ovarian development: the functional importance of germ cell interconnections. Fertil. Steril. 20: 176-189 (1969).

Gondos, B. and R. Zemjanis: Fine structure of spermatogonia and intercellular bridges in Macaca nemestrina. J. Morphol. 131: 431-446 (1970).

King, R. C. and H. Akai: Spermatogenesis in Bombyx mori. I. The canal system joining sister spermatocytes. J. Morphol. 134: 47-56 (1971).

Koch, E. A. and R. C. King: Further studies on the ring canal system of the ovarian cystocytes of Drosophila melanogaster. Z. Zellforsch. 102: 129-152 (1969).

Luft, J. H.: Improvements in epoxy resin embedding methods. J. biophys. biochem. Cytol. 9: 409414 (1961).

Marsland, D. and J. Landau: The mechanisms of cytokinesis: temperature-pressure studies on the cortical gel system in various marine eggs. J. exp. Zool. 125: 507-539 (1954).

Mercer, E. H. and L. Wolpert: Electron microscopy of cleaving sea urchin eggs. Exp. Cell Res. 14: 429-632 (1958).

Millonig, G.: A modified procedure for lead staining of thin sections. J. biophys. biochem. Cytol. 11: 736-739 (1961).

Nagano, T.: Urogenital organ. In: E. Yamada, K. Uchizono and Y. Watanabe (general editors): Fine structure of cells and tissues. Electron microscopic atlas, Vol. 3. Tokyo-Osaka, Igaku-Shoin Ltd, 1967.

Nicander, L.: An electron microscopical study of cell contacts in the seminiferous tubules of some mammals. Z. Zellforsch. 83: 375-397 (1967).

Nicander, $\mathbf{L}$. and L. Plöen: Fine structure of spermatogonia and primary spermatocytes in rabbit. Z. Zellforsch. 99: 221-234 (1969).

Oakberg, E. F.: A description of spermatogenesis in the mouse and its use in analysis of the cycle of the seminiferous epithelium and germ cell renewal. Amer. J. Anat. 99: 391-414 (1956).

Roosen-Runge, E. C.: Untersuchungen über die Degeneration samenbildender Zellen in der normalen Spermatogenese der Ratte. Z. Zellforsch. 41: 221-235 (1955).

Ruby, J. R., R. F. Dyer, R. F. Gasser and R. G. Skalko: Intercellular connections between germ cells in the developing human ovary. Z. Zellforsch. 105: 252-258 (1970).

Rudy, J. R., R. F. Dyer and R. G. Skalko: The occurrence of intercellular bridges during oogenesis in the mouse. J. Morphol. 127: 307-340 (1969).

Schroeder, T. E.: The contractile ring. I. Fine structure of dividing mammalian (HeLa) cells and the effects of Cytochalasin B. Z. Zellforsch. 109: 431-449 (1970).

Slauterback, D. B.: Cytoplasmic microtubules. I. Hydra. J. Cell Biol. 18: 367-388 (1963).

Swierstra, E. E. and R. H. Foote: Cytology and kinetics of spermatogenesis in the rabbit. J. Reprod. Fertil. 5: 309-322 (1963).

Tres, L. L. and A. J. Solari: The ultrastructure of the nuclei and the behaviour of the sex chromosomes of human spermatogonia. Z. Zellforsch. 91: 75-89 (1968).

Vilar, O., C. A. Paulsen and D. J. Moore: Electron microscopy of the human seminiferous tubules. In: (ed. by) E. Rosemgerg and C. A. Paulsen: The human testis. (Proceedings of workshop
conference, Positano, Italy, 1970). New York-London, Plenum press, 1970. (Vol. 10, p. 63-74).

Zamboni, L. and B. Gondos: Intercellular bridges and synchronization of germ cell differentiation during oogenesis in the rabbit. J. Cell Biol. 36: 276-282 (1968).

外川八洲雄

干951 新潟市旭町 1

新潟大学医学部

泌尿器科学教室
Dr. Yasuo Togawa

Department of Urology

Niigata University School of Medicine

951 Niigata, Japan 